\title{
The Play's the Thing: A Multi-text Approach to Acting Shakespeare
}

\author{
By Laura Wayth ${ }^{*}$
}

\begin{abstract}
There is no one, true definitive version of Shakespeare's plays. Shakespeare wrote his work to be performed live rather than to be read. When his plays were ultimately set down in writing, they were often cobbled together from multiple sources (some sources more reliable than others). Because we cannot trust that any one particular written account of Shakespeare's plays are the exact version that Shakespeare gave to his actors, there is ambiguity and variation among the texts. Without a single authoritative text, Shakespeare's editors have the power, through their own research and choices, to drastically sculpt and alter the meaning of his plays. The word and punctuation choices made by the editor, and even the visual layout that editors' choose, can have enormous ramifications in the world of the actor. Whole scenes, soliloquies and even characterizations can be profoundly affected by editorial choices. If there is no one definitive written text of Macbeth, should not the actor playing Macbeth investigate different editorial choices to create the most exciting Macbeth that he can? If there is no authoritative text of Othello, how can the actor playing Desdemona know that she is making the most compelling choices possible? This paper investigates a muti-text approach to teaching and acting Shakespeare. We will identify a method for working with multiple editions of Shakespeare texts by comparing and contrasting the following texts: The Riverside Shakespeare, The Arden Shakespeare, The Bevington Shakespeare, and The Oxford Complete Works. We will use scenes from the plays Othello and Macbeth as launching points to see the profound differences in the edited plays, and to learn how these differences can lead to incredible artistic conversations and discoveries for both students and professional actors. There is no one, true, definitive version of Shakespeare's plays. If there is no single authoritative version of his plays, to limit the actor to working from only one edited version of the text of a Shakespeare play is to limit myriad acting possibilities and potentials for storytelling.
\end{abstract}

\section{Many Shakespeares, Many Texts}

We think of a Shakespeare play as being a Shakespeare play, but because of the audience that Shakespeare originally wrote for and the time period that Shakespeare was writing in, this was not the case. Shakespeare wrote plays for actors to act, with the sole purpose of pleasing a live group of theatre patrons; i.e. he wrote his work to be performed live for an audience rather than to be read. Therefore, during the time in which Shakespeare was creating his plays, not only was it unnecessary to commit a play to writing, it was fiscally foolish to do so. A written version of a play could be obtained by a competing theatre company and presented to the public by that company, posing substantial competition to Shakespeare and his players.

Even though Shakespeare had no interest in publishing the works, during his lifetime many of his plays did make it into print; often without his knowledge or his supervision. Unscrupulous actors sometimes recalled the

\footnotetext{
*Assistant Professor and Coordinator of Actor Training, School of Theatre and Dance, San Francisco State University, USA.
} 
text of plays from memory and sold the text to unscrupulous rival theatre companies. Some plays made it into print by more ethical means. All of these printed versions emerged as Quartos-small, cheap and often poorly printed single editions of the plays (so called because they were folder into quarters at printing). It was not until seven years after Shakespeare's death, however, that a collection of all of his plays was assembled by his partners, William Condell and John Heminge, and printed in a single bound volume. This volume is referred to as the First Folio. Although the First Folio is a collection of Shakespeare's plays, it is by no means a definitive version of the plays. Significant differences between the texts of the Folio and the various Quarto texts exist. Since Shakespeare himself did not set these words in print, and each written volume is a re-creation of Shakespeare's verbally presented play, we cannot say with conviction that any one of these versions is the true version of the play as Shakespeare created it.

Without such a single authoritative text, Shakespeare's modern editors have the power, through their own research and choices, to drastically sculpt and alter the meaning of his plays. The word and punctuation choices made by the editor, and even the visual layout that editors choose, can have enormous impact on the meaning of the text. Some differences present themselves on a smaller scale, such as differences in individual word choices. Some differences present themselves in very large ways (The Tragedy of Hamlet, for instance, has a different number of soliloquies spoken by the title character, depending on which edited version of the text you are reading). While a casual reader of the plays may not notice these differences or find them significant, for the actor, any kind of difference-large or small-can have a huge impact on the work as a whole.

\section{Ambiguity is an Opportunity for the Actor}

Most often, if an actor is studying the role of Hamlet, he is given a single text to work from. The acting teacher (or theatre director) usually provides the actor with a well-edited, well-regarded single version of the text.

The actor who works from a single text can only execute the choices made by that text's editor. He is locked into making choices that have essentially been made for him.

But what if teachers or directors allowed and encouraged the actor to be his or her own creative scholar? What if the actor learned a way of working that compared and contrasted several differently edited versions of the text, noting significant distinctions and their potential effects on characterization, and then, fully informed, created his own vision of the play, scene or soliloquy? In this way, he could take the best word choice from one editor 
and combine it with the most compelling punctuation choice from another editor, creating the most exciting and playable choices possible to tell the story.

\section{A Multitude of Hamlets}

To illustrate and explore this idea, here is an example-the first two lines from Act I, scene ii of Shakespeare's Hamlet. This is Hamlet's first soliloquy in the play; and what better place to start, for it is here, in the first two lines of his first speech, that we as an audience will glimpse into Hamlet's inner life for the first time.

Here are four differently edited versions of lines 129 and 130. I have chosen these particular editions because they are some of the more widely used editions of Shakespeare's plays.

\section{The Oxford}

The editors of The Oxford edition of The Complete Works note the opening lines of Hamlet's soliloquy as follows: ${ }^{1}$

\section{O that this too too solid flesh would melt, Thaw, and resolve itself into a dew.}

In this edited version of the soliloquy, the word "solid" is used. For the actor, the word solid brings up images of tangible, substantive flesh melting into water and vapor. It is a very visceral image that connotes something whole and corporeal evaporating and vanishing. It is the idea of death itselfexistence transforming gently into non-existence.

Also note the way in which the editors have punctuated these two lines. The comma at the end of line 129 suggests that this is where the actor should pause and breathe. The actor again would pause after the word "Thaw", but would treat the end of the line after the word "dew" (which is unpunctuated) as an enjambment, continuing his vocal energy (and the thought) on to the next line.

1. Stanley Wells, Gary Taylor, John Joewett and William Montgomery, William Shakespeare The Complete Works (Oxford, UK: Clarendon Press, 1986), 740. 


\section{The Bevington}

Next, let us look at the same text as it appears in The Necessary Shakespeare, edited by scholar David Bevington: ${ }^{2}$

\section{$O$, that this too too sullied flesh would melt, Thaw, and resolve itself into a dew!}

Here, Bevington chooses to use the word "sullied" in line 129. Sullied has a very different meaning and gives rise to a very different series of images than the word "solid" which we saw used by The Oxford. "Sullied" brings forth the image of dirt, grime and filth. Literally, something that has been sullied is something that has been defiled. Here we see that Hamlet, through the knowledge of all of the corruption surrounding him, has been tainted; his purity has been destroyed. He has been sullied. Enveloped in so much corruption, Hamlet's only relief, as he sees it, would be to leave his impure body.

The image of filth, grime and contamination is one that is prevalent in the play. Using this choice in the opening soliloquy sets this Hamlet up nicely to play the later scenes in Act III with Gertrude, where he speaks most graphically about filth and corruption.

Also, notice that in this version there is a comma placed after the initial "O". This would suggest to the actor delivering the soliloquy that "O" is a drawn out and labored sound. It is very different to hear the actor speak:

\section{O that this too too solid flesh}

Than it is to hear the actor speak:

\section{O, (pause) that this too too sullied flesh}

Although it may seem like a small detail, the placement of the comma after "O" in the first beat of the first line literally slows the energy of the speech, making the line heavier and making the "O" more fraught and dense.

In this version also note that there is no enjambment after the word "dew" as there is in the first selection from The Oxford. Instead, the editor has chosen an exclamation point. Not only does Hamlet's thought end on the second line in this version of the text (rather than continuing on to the next line) it ends with a bang!

2. David Bevington, The Necessary Shakespeare (New York: Addison-Wesley Educational Publishers Inc., 2002), 537. 
Also, in this version there is a comma placed after the word "Thaw". The comma both after the "O" and after the word "Thaw" create opening lines to the soliloquy that are weightier and more labored than more sparsely punctuated versions.

\section{The Arden}

Exploring further text possibilities, the editors of The Arden Shakespeare Complete Works write lines 129 and 130 as follows: ${ }^{3}$

\section{O that this too too sullied flesh would melt, \\ Thaw and resolve itself into a dew,}

Again, note the use of the word "sullied" and all that this word implies. This version, however, sans punctuation in the first foot of both lines 129 and 130, suggests an opening that is more flowing and driving than the more heavily punctuated version seen in the Bevington edition.

\section{The Riverside}

Looking at one last version of these two lines of Hamlet's text, here is The Riverside Shakespeare: ${ }^{4}$

\section{O that this too too sallied flesh would melt,} Thaw, and resolve itself into a dew!

Note yet another word choice; "sallied" is chosen by this editor rather than the words "solid" or "sullied". This word offers yet another set of possibilities. The word sallied has two potential meanings: to venture off of the beaten path or to leap forth suddenly. Both meanings of the word offer distinct possibilities for this Hamlet.

In the first meaning of the word, Hamlet could be speaking, again, of a loss of his innocence; only in contrast to the word "sullied" which connotes filth, the word "sallied" suggests a movement away from the established norm (something that has certainly happened to Hamlet during the recent turn of events in his life).

This word choice offers yet another interesting possibility, and this option taps into yet another central, essential theme in the play; the idea of

3. Richard Proudfoot, Ann Thompson and David Scott Kastan, The Arden Shakespeare Complete Works (Surrey, UK: Thompson Publishing Company, 1998), 296.

4. Blakemore G. Evans, et al., The Riverside Shakespeare (New York: Houghton Mifflin Company Inc., 1997), 1193. 
action. Viewing the word "sallied" as a sudden leaping forward, we could view the line, "O that this too too sallied flesh" is a reference to rash and hasty action. Hamlet fears taking decisive, irrevocable action, and yet feels that he must act. Perhaps, the only way for Hamlet to prevent himself from taking such sudden action in his current state of confusion and turmoil is to wish his own demise.

\section{The Creation of the Unique Hamlet}

In each case above, a single word creates an entirely different world of meaning. A variation in punctuation creates the difference between a meditative, contemplative, reflective Hamlet, and a driving, vibrating, manic and intellectually electric Hamlet.

But how can the actor work in this new way? He must look at a few different possibilities, side by side, and decide which editor's choices are the most compelling and the most interesting to him.

Were one to examine Hamlet's first soliloquy in its entirety, one would see that the first two lines that we have looked at in-depth are only the beginning of all of the many possibilities, not only in this speech, but throughout the play.

Interrogating a soliloquy in this manner becomes an exciting game for the actor. A single edited version of the text of Hamlet given to the actor generates an inquiry; multiple texts confronting the actor create an active and immersive dialogue. By investigating several texts and making his own choices, the actor delves more deeply into the mind of Hamlet than he might otherwise. No longer is he a passive voice delivering words on a page, but he viscerally engages with, dismantles and reassembles Hamlet's complex psychology.

To me, this is the only way to truly investigate a play as demanding and nuanced as Hamlet, and the only way to begin to do justice to a character as multifaceted, complex and achingly self-aware aware as he is.

Acting is all about choices. As acting teachers and directors, we always tell our actors to make the most compelling choice possible, to take the biggest risk imaginable and to connect as greatly with the character's heart and mind as possible.

To make the big choice, the compelling choice and the connected choice, the actor needs to know what all of the possible choices could look like-and then, and only then, to choose.

It is what Shakespeare, the ultimate questioner of all things, would have wanted. 


\section{Bibliography}

Blakemore G. Evans, Harry Levin, Herschel Baker, Anne Barton, Frank Kermode, Hallet Smith, Marie Edel and Charles H. Shattuck. The Riverside Shakespeare. New York: Houghton Mifflin Company Inc., 1997.

Bevington, David. The Necessary Shakespeare. New York: Addison-Wesley Educational Publishers Inc., 2002.

Proudfoot, Richard, Thompson, Ann and Kastan, David Scott. The Arden Shakespeare Complete Works. Surrey, UK: Thompson Publishing Company, 1998.

Wells, Stanley, Taylor, Gary, Jowett, John and Montgomery, William. William Shakespeare The Complete Works. Oxford, UK: Clarendon Press, 1986.

Frampton, Saul. "Who edited Shakespeare." theguardian.com. Last modified July 12, 2013. http://goo.gl/Z2s1Q2. 
